\title{
EMPOWERMENT AND ITS IMPLEMENTATION IN THE PROCESS OF COUNTERACTING THE PHENOMENON OF YOUTH AND ADULT SOCIAL EXCLUSION - REPORT ON PARTICIPATION IN AN INTERNATIONAL PROJECT UNDER THE 2014-2016 ERASMUS + STRATEGIC PARTNERSHIP PROJECT
}

\author{
JOLANTA JARCZYŃSKA \\ Faculty of Pedagogy and Psychology, \\ Kazimierz Wielki University, Bydgoszcz, Poland \\ e-mail: jolanta.jarczynska@ukw.edu.pl \\ BARTŁOMIEJ WALCZAK \\ Faculty of Pedagogy and Psychology, \\ Kazimierz Wielki University, Bydgoszcz, Poland \\ e-mail: walczak.ukw@gmail.com
}

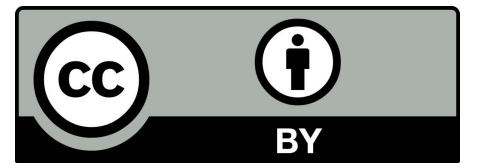

\begin{abstract}
The aim of the article is to describe the empowerment process and its implementation in social work in the context of counteracting social exclusion in youth and adults based on the example of the project carried out in the years 2014-2016, titled: "Development of the empowerment of educators and beneficiaries in the field of youth at risk and social exclusion", co-financed from European Union funds within the Erasmus + programme, Action 2: Strategic partnership of professional teaching and training, Grant No. 2014-1-FR01-KA2026-008728. The English language concept category of empowerment, which does not have a satisfactory equivalent term in the Polish language, was operationalised in this article. The essence of empowerment in the context of social work was described in the article, pointing to its significance mainly in the scope of counteracting the process of youth and adult social exclusion. Furthermore, the main assumptions of the implemented international project were set out in the ambit of the development of the empowerment of educators as well as of beneficiaries working with persons at risk of social exclusion, and the relationship and reflections of one of the project participants were also shown. An attempt was made in the article on the basis of the experiences gathered within the performance of the international research project to assess the course of the empowerment process and its usefulness in searching for solutions for educational practices in the domain of the social exclusion phenomenon.

Key words: empowerment, strengthening, social inclusion, social exclusion, beneficiary, at-risk group, social work
\end{abstract}




\section{INTRODUCTION}

The extensive applications and usefulness of empowerment can be found in the field of social sciences, mainly in the context of research pertaining to social work (Szmagalski, 1994b; Trawkowska, 2014) and to management (Bugdol, 2006). Empowerment in social sciences mainly refers to individuals and members of discriminated, minority and marginalised groups that are often vulnerable to the social exclusion phenomenon or are already experiencing exclusion from the decision-making process, from the opportunity to exact change, and from broadly understood knowledge (on personal, family, local, state and other levels). The aim of empowerment actions is the achievement of a condition, in which people can regain individual and group control over their own lives, locations, postulates, interests, spaces, rights, and languages, etc. Thanks to this, they are capable of specifying their own needs, life goals and actions, and they have a sense of causation/impact on a series of matters in their own life and their surroundings. This process facilitates increasing an individual's control over their own life, finding faith in oneself and one's own capacity, and social inclusion (Słowniczek OSL, 2016).

The article aims to describe the course of the empowerment process in the context of counteracting youth and adult social exclusion, which took place under the international project titled: The development of the empowerment of educators and beneficiaries in the field of youth at risk and social exclusion financed within the Erasmus+ programme conducted in 2014-2016. The first part of the article deals with the operationalisation of the English term empowerment. Its significance in the context of social work, with particular focus on its main meaning in terms of combating the youth and adult social exclusion process also described in the article. The main assumptions of the implemented international project concerning the development of the empowerment of educators and beneficiaries working with persons at risk of social exclusion in which the empowerment process was activated were subsequently set out. The last part of the article presents an account of one of the project participants along with their reflections. The article closes with some thoughts on the implications of the empowerment process in the field of social work, particularly the problem the of social exclusion of youth and adults on the basis of the experiences collected by means of taking part in the aforementioned international research project.

\section{EMPOWERMENT \\ - DEFINITION PROBLEMS, THE ESSENCE OF THE TERM}

The term empowerment appeared in scientific literature and in global discourse as early as in the 1970s, in connection with the theory of liberation and universal education in South America advocated by Paulo Freire and Saul Alinsky, who were dealing with the organisation and strengthening of local communities in black ghettoes in the United States of America (Duranowski, 
2013). There are many ways in which the term empowerment can be understood and many contexts in which it can be used. This word either functions in its original wording or is translated into different Polish equivalents in Polish literature. Empowerment is a noun in the English language and is mainly used in the English language in academic literature across various social science disciplines (Szarfenberg, 2015). The following words are used for this notional category for the proposed translation into the Polish language: upodmiotowienie (e.g., Moczydłowska, 2013), and uwłasnowolnienie (e.g., UN, 1995), upełnomocnienie (e.g., Gulczyńska, 2014), umacnianie (e.g., KanafaChmielewska, 2012), wzmocnienie (e.g., Krzyszkowski, 2011), uprawomocnienie (e.g., Olejniczak, 2013), and uwłaszczenie (Osborne, \& Gaebler, 2005).

The semantic analysis of the term empowerment performed by Ryszard Szarfenberg (2015) indicates that its meaning refers to the main core of this concept, namely, the word: power, which is translated into Polish as: władza, siła, moc, uprawnienie, zdolność, and energia. The "em-" prefix placed before the word power signalises an active relationship to the meaning of the term, emphasising the focus on change in power, strength and force. In Polish translations, an equivalent of the "em-" prefix is the " $u-$ " prefix, for instance, upodmiotowienie, uprawomocnienie, umacnianie (Szarfenberg, 2015). Hence, the most frequently proposed Polish translation of the term empowerment includes the terms stated above: upodmiotowienie, upełnomocnienie, uwłasnowolnienie, and uprawomocnienie. The same terms for the word empowerment can also be found on the Równość.pl website (Słownik równość.info, 2016). In the OSL dictionary: Organizowanie Społeczności Lokalnej (Organisation of the Local Community) (Słowniczek OSL, 2016), the word empowerment rather means strengthening. It is demonstrated that this is a "process of empowerment, during which individuals, groups, organisations and communities increase/ obtain command and control of their own life and become active participants of social life, taking actions to improve their own situations as well as the situation of the entire community" (Słowniczek OSL, 2016).

Broader considerations of the definition of this term indicate that the word empowerment is the opposite of helplessness. It is both the process and the outcome, namely, the obtained end state, meaning the obtainment of power (strength), thanks to which individuals, groups, communities or institutions can fight for strengthening. It is a strengthening to defend, to independently pursue one's own needs, as well as to strengthen individuals finding themselves in difficult situations, especially the weak, socially or economically inefficient, disabled people, and also those abused by others or by the system (Ornacka, 2013). Empowerment as a process means facilitating, enabling and/or promoting the capacity to function optimally and competently. It is an end in itself with the point being for individuals and groups that are divest of causative capacity to manage to get out of this state and become capable of establishing and rebuilding their own status as persons with equal rights and competent citizens in society. Empowerment in this context covers the individual and the collective dimensions, as well as the subjective and objective aspects. The individual 
dimension is connected with actions and processes the aim of which are to increase an individual's control over their own life, their faith in themselves and their capabilities, equipping/enriching them with knowledge, competencies and skills and abilities. This dimension is also referred to as psychological and is understood as an individual's intrinsic motivation that covers four dimensions: assigning a personal meaning to the work performed by them, familiarity with one's own competences, the conviction of being capable of making proactive choices (self-determination) and the conviction that one's work is worthwhile (Gkorezis, 2011; quoted after: Krawczyk-Bryłka, 2012). The collective dimension, on the other hand, refers to social structures and to barriers and relationships of influence that sustain differentiation and injustice, while at the same time reducing an individual's chances of taking control of their own life. The subjective dimension of empowerment means that it includes an individual's feeling of causation, whereas the objective means the realistic expansion of the scope of causation understood as a sense of inner control or an awareness of the fact that ensuing events are directly related with the specific action of the individual that is participating in them (Słowniczek OSL, 2016).

According to the analysis performed by R. Szarfenberg (2015) assuming that power, strength, and authority can be given and taken away, increased or decreased, the use of the term empowerment is connected with the first element, namely, with giving and increasing strength/power. Nevertheless, the point is not to give, confer and increase it where it is already held, but to do this where it is absent and where there is not enough of it. For example, strength and power should be given and conferred to those that are deprived of it, imparted to those that are helpless; rights should be given to those that have been refused them; and those that are in a worse situation than others or hold lower positions should be strengthened.

Based on the above analysis, it is apparent that the word empowerment possesses positive connotations and relates to human relations since giving, adding or increasing strength, causation, and power to persons that did not possess them earlier or who had them significantly restricted will be associated with changes in the relationships and arrangements functioning to date. If the relation of power or strength consisted of domination, then empowerment may mean: 1) A certain kind of knowledge and attitude: a view and/or conviction that the relation should change for the benefit of the weaker party; 2) the behaviour resulting from this attitude - action intended to strengthen the dominated, namely, the weaker party in the relation; 3) the intended effect of such actions, that is, the effect that consists of the weakening of domination, and making power, strength or rights equal and balanced (Szarfenberg, 2015).

\section{EMPOWERMENT IN THE CONTEXT OF SOCIAL WORK}

The term empowerment is one of the key terms that has been incorporated in the international definition of social work. Its final version developed in 2014 states that social work is a profession that resulted from the practice and scien- 
tific discipline promoting social change, social development, social inclusion, and empowerment, understood as the strengthening of the position of individuals and the liberation of people (Global Definition of Social Work, 2014) Thus, the term empowerment (uwłasnowolnienie/ upełnomocnienie / upodmiotowienie) constitutes an integral part of the international definition of social work which states that it is a profession that promotes social change, problem solving in human relationships, and the empowerment of people to enhance well-being. This term in social or community work is presented as a key concept in defining the very nature of the undertaken actions. The main objective of the concept of community-based development is also the enhancement and strengthening of communities, emphasising the significance of empowerment (Szarfenberg, 2015). In Poland, such an approach is popularised in theory and practice by the Local Activity Support Centre, which publishes the Empowerment - o polityce aktywnej integracji (Empowerment - on the active inclusion policy) journal, as well as by the Social Assistance Council, which established the Empowerment Cooperation Forum, which is a platform for discussion and cooperation that promotes the idea and value of the empowerment concept. A concept of social work that is close to this way of thinking is the one functioning in Poland, a precursor of which was Helena Radlinska. She referred to human strengths in the definition of social work, stating that: "[it] consists of bringing out and multiplying human strengths, facilitating and organising common actions for the good of the people" (Radlinska, 1961, p. 335; quoted after: Szarfenberg, 2015). The strength category was promoted along with the critique of approaches relying on a needs, deficits and problem-centred diagnosis. In the 1990s, it was more clearly linked with the idea of empowerment (Cowger, 1994; Krasiejko, 2010, pp. 49-85; quoted after: Szarfenberg, 2015).

The empowerment approach stems from the basic principle under the democratic social order of respect for the autonomy and dignity of every human person, this means the subjective treatment of citizens and the creation of communities by public administration, social services, non-governmental organisations and representatives of all helping professions. The policy and social services that have been built around the idea of empowerment constitutes an approach that reinforces the causative potential of people, families and groups and, in the event of them being too weak, ensuring that they are capable of actively taking part in public life or reintroducing them to such activity. In social work practice, the empowerment approach signifies striving for the restoration of aid schemes for clients that help them to regain a sense of causality and genuine control over their own lives which is associated with this. This is because social practice proves that it is exactly the sense of helplessness and lack of control that underpins the preservation of life attitudes and the development of social processes that push people out to the margins of society. It is worth highlighting that whether or not these processes result from self-marginalisation (which is the consequence of harmful dependencies, dysfunctions, or being culturally ill-equipped) or from weak people being subject to exclusion processes initiated by others, is of little importance. In both cases, 
rebuilding faith in oneself and a sense of influence on the course of events is an important, if not crucial aspect of the process of coming out of isolation and the process of social inclusion constituting its extrapolation (Empowerment Cooperation Manifest Forum).

The pervasive practice in social work is based on working on the basis of the resources held by the client, their family and the environment. It was built on the conviction of empowerment, the resources of individuals and of the environment, on potential, cooperation, and membership, understood as inclusion in social life. Thus, it was formed in opposition to the concept of working with the client on the grounds of her/his shortcomings and deficiencies. According to Charles A. Rapp, a research-based approach provides clients with new opportunities. It helps the client discover their individual skills and abilities, which play a significant role in solving problems. The main assumption of this idea is the conviction that people are more susceptible to change if they are individuals involved in this process rather than the subjects of change initiated by others (Ciczkowska-Giedzun, 2011b). In connection with this assumption, the trend that currently dominates in social work postulates thinking about the empowerment of not only those people that are supported by social workers, namely, the beneficiaries of such actions, but also of themselves, that is, of the professionals. This way of thinking also accompanied the main assumptions of the international project described in this article, whose objective was the empowerment (upodmiotowienie, uwłasnowolnienie or wzmocnienie) of persons that are at risk of social exclusion, as well as of those working with such people. The characteristics of this project have been presented in the next subchapter of this article. The mentioned trend integrates two important strands, the first of which emphasises the empowerment of supported persons/beneficiaries (the poor, helpless, discriminated, and excluded, etc.), the second of which focuses on the empowerment of professionals/workers, often employed persons (an example of which can be the position of a family assistant in Poland). The integration of both trends, namely, the empowerment of social workers in establishments/institutions or organisations rendering services and the empowerment of clients of such organisations (beneficiaries) is a necessity that is to lead to the greater effectiveness of undertaken measures. The recommendations concerning the need for both trends to be integrated have already been postulated in literature several and even a dozen or so years ago (e.g., Hardina, 2005; Hardina, et al., 2007). A criticism of social work and social services that was only based on one of the two approaches advocated the integration of both trends. Actions that were overly focused on the empowerment of the beneficiaries of social services and those that concerned the empowerment of social workers/professionals alone turned out to be harmful and rather ineffective. In the first case, excessive focus on the self-determination of an individual resulted in neglecting the essence and significance of the mutual dependencies, and the resulting attitude of appreciation, acceptance of others, and empathy. In the second case, the criticism concerned failing to take the individual limitations of persons and groups into account in empowerment, as 
well as the fact of it being conflict- and coercion-orientated and not educationoriented (Wolfensberger, 2011). The integration of both threads is crucial and is aimed at increasing the actual capacity of the participants (the beneficiaries of social services and the professionals working with them) to influence the actions that concern them and, at the same time, increase the effectiveness of such actions.

\section{THE DEVELOPMENT OF THE EMPOWERMENT OF EDUCATORS AND BENEFICIARIES IN THE FIELD OF YOUTH AT RISK AND SOCIAL EXCLUSION: THE CHARACTERISTICS OF THE INNOVATIVE PROJECT PERFORMED UNDER THE ERASMUS+ PROGRAMME}

Empowerment was used in the process of combating the phenomenon of youth and adult social exclusion that was taking place within the innovative international project discussed in this article. The project objectives constitute the answer to the challenges formulated by the European Union associated with working to combat poverty and social exclusion. The project was initiated by a network of social educators referred to as "Educ-Europe" (The European Training for Social Educators) established in 2006, which currently brings together 12 European organisations and institutions operating in the field of child and youth protection belonging to the higher education and educator training sector. The "Educ-Europe" network is gradually expanding by inviting more institutions and organisations to collaborate with it. The project facilitates experts associated within the "Educ-Europe" network to develop and enhance their skills and abilities, increase their employability, exchange knowledge and good practices concerning social inclusion, support families experiencing difficulties in the performance of their educational and care functions and support young people at risk of social exclusion. Eight Educ-Europe associated partners joined the project, namely, the d'Auteuil Foundation from France - the institution that submitted the project to the national Erasmus+ agency and performed the function of the project manager. The foundation has been operating in France for almost 150 years, combating social exclusion of the young and their families. The following institutions and organisations fulfilled partner roles in the project. They were: Haute Ecole de Bruxelles (Belgium); Karel de Grote University (Antwerp, Belgium; CRIPS - Asociatia Cebtrul de Resursesi Informarepentru Profesiuni Sociale (Romania); INFA - Institut National de Formation et de l'Application (France); Fondation Amigo (Spain); CNOS - Centro Nationale Opere Salesiane (SCS) (Italy); and the Kazimierz Wielki University in Bydgoszcz (Poland). The members of these institutions jointly developed the project assuming the transfer of innovation and collaboration, convinced of the need to implement permanent changes in the way that the social actions of beneficiaries are supported and innovations in the scope of training and research methodology. They all participated in each phase of the 
project and activated the mobility of social intervention practitioners, trainers and their beneficiaries. The main message of the project was the promotion of innovative ways of conducting social interventions in the realm of the social exclusion phenomenon, which were meant to be based on the idea of strengthening the beneficiary's position in the social change design and implementation process by bringing out their potential and resources. The possibility of developing the competences of practitioners and professionals working with the beneficiaries of social services was also foreseen in the project. Emphasis was also placed on the development of intervention methods. Such an assumption is in line with the dominant striving in contemporary social work to the empowerment of not just those that are supported by social workers, namely, the beneficiaries, but also of themselves, that is, the professionals.

The issue of social exclusion analysed under the project concerned two groups of persons needing help: youth and adults. The main aim of the research work in both cases was the empowerment of persons at risk of social exclusion or already excluded persons. Therefore, two significant areas of social practice interests were planned within the research work, also referred to as action-research sessions, namely: the support of adolescents facing being in conflict with the law, and working with adults that have found themselves in a very difficult life situation. Due to the interdisciplinary nature of the project, its interculturality and the participation of persons of different professions, as well as beneficiaries with different life experiences, the intermediate objective of the project was the exchange of good practices drawn from its participants. An important project objective was increasing the mobility of researchers. Four international action research groups were established to fulfil the above project goals, who worked on the basis of action research methodology during four sessions (which took place in Paris, Bydgoszcz, Antwerp, and Rome). One action research group which was comprised of practitioners, theoreticians and beneficiaries was appointed to work on each of the identified areas. Each of the teams was led by a pair of facilitators, who were experts in the social work area as well as in action research. The first two groups concurrently took part in five-day workshop sessions that were held in Paris (24-29 November 2014) and which were later continued in Bydgoszcz (18-22 May 2015). Each of the groups was required to conduct a diary recording the results of the groups' daily work, the thoughts and reflections of the group participants as well as the postulates and formulated research questions. These two groups created 4 diaries in total within the first year of work (one diary from the session in France and one diary from the session in Bydgoszcz conducted by each of the groups). The following year, two newly appointed groups which were comprised of beneficiaries, professionals, as well as of educators of social workers and facilitators worked on the same research areas. The first meeting of these working groups was held in Antwerp (9-13 November 2015), and the next in Rome (1-5 May 2016). These two teams carried out exactly the same objectives as the previous teams and also conducted diaries at each meeting. A crucial period in their work was the interval between the first and second working meeting of 
each of the groups. This time was to facilitate the personal reflection of each of the group participants, undertaking research and interventions in practice, testing and implementing new methods, techniques and ways of working with socially excluded persons. It was meant to facilitate searching for new methods of working with socially excluded persons as well as testing their efficiency.

Apart from the eight work diaries created by each of the groups, the final outcome of the project also included: INFA two e-learning educational modules constituting the final outcome of the work of the international team of experts that prepared thematic training courses connected with the issue of social exclusion. Both educational modules, namely: 1) empowerment in the context of social support for minors with issues involving Justice, and 2) empowerment and social work with adults living in a highly precarious situation, will be prepared in English and French. They will contain interactive work pathways and audiovisual material (short films, interviews, and presentations) facilitating the perception of the presented training content. A test was developed for each module, enabling the measurement of knowledge and acquired competences and facilitating an initial evaluation of the training course. The training is addressed to students of pedagogy, psychology, sociology, and especially to students of social work and related fields as well as for the beneficiaries of aid activities and professionals wanting to raise their competences. Open access to e-learning courses is planned at the turn of 2016 and 2017. The training website will be administrated by the French partner of the "Educ-Europe" network: INFA, which will also be able to be accessed from the "Educ-Europe" website: www.educ-europe.ue.

The International symposium titled: "How to Use the Force Within Us," which was held in Valencia, in Spain, constituted a summary of the work of the research teams under the implemented project. The main organiser of this symposium was the Spanish "Educ-Europe" network partner and one of the partner organisations in the project: The Amigo Foundation. The central idea of the seminar was to disseminate information on the implemented project among the invited guests, and the presentation of preliminary outcomes of the work, including the social intervention tools.

\section{A REPORT AND REFLECTIONS ON PARTICIPATION IN THE PROJECT OF ONE OF THE PROJECT PARTICIPANTS}

This part of the article presents the report and reflections of one of the Polish participants in the earlier described project, who admits that they found it to be an incredibly valuable experience. This is his account:

Participation in the „Development of the empowerment of educators and beneficiaries in the field of youth at risk and social exclusion" project gave me many interesting experiences and also enabled me to make new acquaintances, exchange good practices and deepen my knowledge and skills required in the social worker and educator professions. I was recommended to be on the project by Professor Maria Deptuła, the Head of the Chair in which the project coor- 
dinator, dr Jolanta Jarczyńska, and other team members work. The reason for this was my knowledge of the English language and my personal experiences which I had shared with the Professor when I was her student in my second year of pedagogy. I once told her about my family, which had numerous problems, about the process of building my resistance to the adversities of fate, about benefitting from the help of a psychologist, and about the experiences that spurred to me change my life. The help that I had received in the difficult periods of my life helped me to understand how important it is to support the people that care for us but it also became my driving force, my empowerment. Knowing how important it is to share difficult experiences with people that can later use them to help other victims, I decided to take part in the international project to which I was invited. Although I was formally submitted to take part in the project as a beneficiary, it quickly turned out that I fulfilled two important roles in the project. The first of them was the role of a beneficiary of psychological assistance, who shares his experiences within the group and talks about the developed coping strategies connected with searching for and receiving help. The second was the role of a professional that has been working with children, adolescents and their parents for three years. In this role, I shared how my experiences can be harnessed to help others needing support.

Thus, after several months of preparations for the trip, familiarisation with the project documentation and discussions with the coordinator, the time came to go to the first five-day meeting of the members of the action-research group that took place in Massabielle in Saint Prix near Paris. We started on the project work from day one. The group leaders referred to as the facilitators of the group were introduced to us. Our task was to present our role in the project and to talk about ourselves and our work. The workshop group working on the issue of the development of the empowerment of educators and beneficiaries in the field of social exclusion, which I took part in, was comprised of 15 members. These persons were delegated by each of the partners taking part in the project. The mentioned workshop group was mainly comprised of social workers who dealt with the phenomenon of social exclusion, homelessness and immigrants on a daily basis. Experts in the field of social economy and university teachers also shared their experiences. The group was supported by three beneficiaries who experienced help in difficult life situations and who could share their experiences with others today. I was one of these beneficiaries. The remaining persons represented the d'Auteuil Foundation from France and Haute Ecole de Bruxelles from Belgium. Each of the participants was prepared and completed the first task of presenting their profession, delegating institution and the scope of their aid actions and competences. Once we became acquainted, we could start the proper project work.

The facilitators representing the d'Auteuil Foundation and Haute Ecole de Bruxelles planned a five-day session and initiated deliberations on the empowerment concept. This term has many meanings and, depending on their reference to various areas of social and business life, can be interpreted differently. Our group was meant to develop its own definition. 
Due to the many meanings of this concept, intensive discussions concerning its meaning were held almost until the third day of the workshop work. Today, after two workshop meetings, the concept of empowerment is comprehensible for me. For me, it means "the possibility of regaining control over one's own life in order to achieve a goal" (Krasiejko, 2010, p. 50). The reinforcement of own strength and the formation of a resistance to risk factors is the main assumption of the empowerment approach. Working on resources assumes the conviction that people are more susceptible to change when they are entities involved in this process rather than when they are the subject of changes initiated by others. This facilitates the search for resources in every person and their environment. Also the difficult, traumatic and painful experiences for an individual can constitute a source of challenges and opportunities. Thus, it is worth striving to ensure that social workers get to know their clients as far as is possible. In this way of approaching working with individuals, social workers can encourage their clients to define their own world, problems, aspirations, and resources thanks to which they can face the future of their dreams. In this way, the beneficiary keeps control of her/his life by activating her/his personal resources (Ciczkowska-Giedziun 2011a). However, returning to the Paris workshops, I would like to point to the group process that took place there. Each of the participants eagerly proceeded to take on work. All day long, we would write up cases according to the project concept and discuss country system solutions that have been implemented to help those that are socially excluded. During our group discussions, we also shared our thoughts and ready ideas for solving various difficulties, which were often comprised of complicated social and social welfare situations. We managed to go on interesting trips to Paris where we could visit centres specialising in helping socially excluded individuals. In one of the day care centres, which I would call a shelter for the homeless, we met several of our countrymen whose fates took such an unfortunate turn of events that they ended up homeless in a foreign country. We were, of course, very moved by their stories and they reinforced the necessity of helping and supporting those affected by social exclusion. After our return from the study visits in these centres, our next task involved analysing what we saw and heard there. We assessed the positive aspects of the operations of these centres and also critically assessed certain operational procedures that were in place there. The discussions were heated but substantive. Each of the participants presented their own viewpoint and their own visions of providing help and assistance. Both the professionals and the beneficiaries alike agreed on the scope of the required help and assistance in order to improve the situations of the persons that have found themselves in difficult life circumstances, issues connected with practice and implementation, however, were subject to many discussions. The beneficiaries all agreed that the theory of developing support plans does not entirely follow the specific and practical actions in this scope. The presence and involvement of each of the parties taking part in the support actions is always absolutely necessary. Despite the slight differences, the empowerment process was very dynamic in our group. The involvement 
and common goals and objectives became our process of awakening our inner strengths to help others.

During this work, I felt incredibly useful and an important element of our team. At times I felt emotionally torn apart; when I saw people in difficult life situations, I felt the need to help them. These images representing the phenomenon of social exclusion reinforced my role in this project. I was aware of the fact that I can be among people that perhaps have a certain impact on the living conditions of those excluded persons only thanks to the understanding that I have of my own experiences, their analysis, and a comprehensive view of my own life. The work that was carried out during the project also reinforced my way of thinking about myself, about how important it was for me to receive help from those closest to me, from the most significant persons in my life. This excitement and euphoria led me to a better understanding of the aid procedures. I also experienced many positive observations when some of the professionals were giving their attention to the fate of the persons that we met in the aid institutions in Paris. This strengthened my thinking that they are truly concerned for the well-being of the beneficiaries and it is not just a facade. I felt satisfied; I knew that the process of reinforcing my strength is shifting to a higher level. As one of the three beneficiaries, I must admit that the experiences of working in a combined group made up of professionals and beneficiaries, were very necessary. Thanks to these meetings, each party could see the way of perceiving the social exclusion problem from the perspective of the other party. Also observing the work of the remaining beneficiaries in our project, I must admit that defensive, justifying, and sometimes criticising behaviour did occasionally appear, particularly directed at the decision-makers and at the proposals of aid actions discussed in our group. This surprised me, particularly because I thought that it was precisely us, the beneficiaries, that should be the most intent on getting the most out of this project. The words themselves, however, did not directly attack the group process, which was taking a proper course. I can see their behaviour and ways of expressing their views about difficult life circumstances more in the category of a manifesto of emotionality that they summoned when discussing something that concerned them.

The last two days were spent on posing questions that can be of help to us as the subject and objective of our research in the interim between the next meeting in Bydgoszcz. Once again, each of the participants got involved as much as they could in developing the end result of our Paris research-action. In view of the many nationality-, political-, economic-, social- and ideologicalrelated differences, we managed to pose two research questions to which we were to search for answers. The first of them was: How the social worker can create conditions to enable him/her and the beneficiaries who are in a situation of social exclusion to facilitate their resilience? The second was: How the social worker can ask/require better social, economic, political and personal conditions for the beneficiaries and for himself/herself?

Our main aim was to find the most precise answers as possible these questions. The results of our search and research were to open the next phase of the 
research-action group in Poland. However, before I move on a short description of my research, it would be worthwhile mentioning an added end result of our work in Paris. This output consisted of the development of a researchaction journal, also referred to as Diary No.1), which was meant to contain any comments and work entries performed during our workshops. We managed to develop it and thanks to the information that it entailed, each of the participants could calmly follow the course of our common work even after it came to an end.

Coming back to my work on the posited questions in the first phase of the project, I would like to mention that it was meant to consist of creating a new methodology and its specific assumptions. It was meant to be work searching for certain indications that, once discussed, could help in finding the answer to our burning questions. This is exactly the work I carried out. Analysing the resources available on the internet and in the social work, pedagogy and sociology references available at my University, I managed to obtain potential answers to the questions posed earlier. Additionally, I confronted them with three scholars, and four pedagogy, sociology and social work students, which reinforced my conviction that their selection was right.

Thus, the results of my work were only waiting for our next meeting to begin, which this time was to be held in Bydgoszcz.

The second phase of the research-action group meetings began in May 2015. We met and worked in the Main Library of my alma mater. I had huge expectations towards the continuation of the project. I was looking forward to the next meeting. In Bydgoszcz, we started by welcoming our new facilitator leading our group, who replaced the representative of Haute Ecole de Bruxelles from Belgium in this role. The leader surprised us with his excellent preparation, knowledge about us and familiarity with our names. He would address each of us by name right from the very start - which he most certainly prepared for by analysing our statements and entries in the work journal from Paris. Thanks to this, he was immediately accepted by the group and received our trust. Similarly to Saint-Prix, during the first meeting in Bydgoszcz we were presented with the five-day works schedule and together arranged the entire fine details connected therewith.

The next stage of our meeting was to present the outcomes of our work. Each of the participants presented the results of their work, after which the whole group analysed them substantively. Many questions were asked, there were numerous comments, and comparisons were being made in the scope of aid solutions used by establishments and institutions in various countries. This aspect of the project work initiated a group crisis. We continued to fulfil our week's schedule. Just like in Paris, we visited aid and support centres for socially excluded persons. These included a shelter for homeless men in Torun and a shelter for homeless single mothers in Bydgoszcz. An analysis of the operational procedures implemented in certain centres helped the project participants understand the idea of these kinds of institutions operating in our country. At our next meetings, we would refer to the presentations of our 
research and compared them with the practices taking place in different European countries. Unfortunately, the exchange of opinions was not as cohesive as it was earlier. The group of Italian participants felt a huge deficiency in the work that we performed. They thought that we should strive to develop something that will help them in fighting Italian policymakers for those finding themselves in difficult life situations. After lengthy discussions and attempts at understanding the many viewpoints represented by the project participants there was a drop in the level of energy within the group. We then asked for a longer break in order to abreact in order to release the ensuing emotional tension. After a break, a discussion was started on what exactly the project organisers expect from us. I was surprised; I felt that our foreign colleagues were not fully oriented in terms of their participation in the project. I was afraid that the misunderstanding of the project main objective, which was to develop cooperation and exchange good practices, would lead to the group falling apart. The facilitators of our group were meticulously taking note of our statements, observing the behaviour of the group participants, and carefully listening to their comments, while at the same time assessing them. Fortunately, the work became clear after many hours of work. That was when the group process was restored. The emotional tension that accumulated in the participants dropped to the level of a substantive discussion.

For me, a sufficient factor for further work on my resistance was the confrontation of my way of thinking and experiences with those of the other beneficiaries and professionals. It became a new challenge for me, which helped me to understand others and interpret the social situation and phenomenon of social exclusion properly. After the Bydgoszcz meeting, the next workshop group research-action journal (Diary No. 2) was created, constituting a source of information on the work performed in Poland.

However, our work in both France and Poland was not just burdened with the project work. We spent many wonderful moments sightseeing together in Paris, Bydgoszcz and Torun. Thanks to such sightseeing trips we could abreact the entire intellectual effort that was put into the work on the project. I still wonder to this day what my reflections on the topic of participation in this project are. With time, I am seeing which resources I managed to harness in my further professional and scientific work at university. Earlier, after returning from France, I had many objections concerning the organisation of the language barrier that arose. Although the official project language was English, many persons did not have a communicative command of it, which gave rise to multilingual communication. Despite my good command of English, I sometimes felt that I could not fully understand the message being conveyed. I found it difficult to listen to utterances in French, which were translated into English, and vice versa. The process of interpreting and explaining what we mean consumed a lot of the group's time. It was surprising for me, however, that despite these difficulties, the group process was showing progress. The participants were harnessing all their energy in the project objectives. I can fully ascertain that the empowerment process occurred in our group during 
the first workshops, which included my fascination and new energy to act.

In Poland, in terms of language, things were much better, although interpretation of additional languages like Spanish and Italian did occur. This was, however, much freer and more practical. Although here, in my view, the empowerment process showed signs of stagnation and even regression until the moment when the framework of the project was defined and its true assumptions and objectives were presented. That was when everything was back on the right tracks. From the very beginning, I treated my participation in the Educ-Europe project as a challenge and opportunity for personal and scientific development. And that is exactly what happened. Thanks to my participation in the project, I acquired many new international acquaintances, I got to know an organisation working for people in difficult situations, I shared good practices and became familiar with the ideology of helping in other European countries. The project showed me just how difficult it is to develop a common tool to work with persons living in very difficult conditions in various European countries. Today, I know that our two meetings were an introduction and reconnaissance for the next research-action group. Based on our experiences, new meetings can bear fruit in more substantive work on the phenomenon of social exclusion. Personally, I am very grateful for being given the opportunity to take part in the project. Thanks to such experiences, I can develop further in academic and social terms.

\section{SUMMARY}

The phenomenon of social exclusion is one of the priority social problems in Europe which has intensified in recent years, which is connected with the need to monitor and evaluate current social actions and design and implement new solutions facilitating help and assistance extended to at-risk persons and social groups. Such actions are undertaken by governmental and non-governmental centres in many countries, and it is also a top priority in the European Union. The international project presented under the article is an example of innovative action combating this social problem. Its innovativeness consists of implementing action research methodology in the design process of social actions and taking into account the current trend in social work postulating thinking about the empowerment of not just those that are assisted by social workers but of the social workers themselves. An added value of the conducted research within the discussed international project was the emancipation of the beneficiaries that the phenomenon of social exclusion pertains to and the evaluation of own practices undertaken by team-member professionals.

An analysis of the work undertaken under the implemented project can reinforce the conviction that the empowerment of socially excluded persons is a continuous and difficult process. Actions connected with social inclusion of excluded persons consist of encouraging the members of a given community (group) to enter into interactions and dialogue with other people. The creation of situations enabling getting to know each other and establishing relation- 
ships, which is what happened in the project work presented in this article, is conducive to this. Inclusion is connected with the creation of a platform for dialogue with the aim of reducing human fears, enhancing a sense of security and leading to the participants of the group understanding that the improvement of their quality of life depends on them all, on their mutual responsibility for each other and for the common good.

Many factors influence the empowerment process. It is above all important to remember that the personality traits and social competences of persons working with the project participants belong to the one of the most important of them. These persons fulfilled the roles of facilitators in the discussed project. They enjoyed the trust and confidence of the group participants, constituted a positive authority and could identify and understand their needs. These persons were communicative, supportive, friendly and focused on the members of the group, both the beneficiaries and the professionals alike. They proactively interacted with the participants and supplied them with feedback concerning the proposals raised and the input in planning and managing project work. This attitude manifested by the facilitators definitely reinforced the process of raising the self-esteem of the beneficiaries, of socially excluded persons and also helped them to become more involved in project work. Thanks to the implementation of the empowerment principle, it seems possible to: build good relations between project participants (beneficiaries and professionals); to build a sense of ownership and joint responsibility for the project; to increase the efficiency of the project by better implementing the undertaken activities; to share acquired knowledge; to drive social forces dwelling in the group participants and to gain access to a variety of resources (human, institutions, etc.).

In view of the experiences resulting from the performance of the two-year project, it is possible to state that in the case of complex, multiannual projects, it is worth making an empowerment plan that will regulate the scope and manner of direct involvement of the project participants in the implemented forms of support in a time horizon. In the empowerment plan, it would be worth including, for instance, the principles applicable to participation in the process of creation and modification of a work schedule, the implementation of actions, the evaluation of the project and the popularisation of its results.

\section{REFERENCES}

[1] Bugdol, M. (2006). Wartości organizacyjne. Szkice z teorii organizacji i zarządzania [The organisational values. Sketches from the theory of organization and management]. Kraków: Wydawnictwo UJ.

[2] Ciczkowska-Giedzuń, M. (2011a). Nowe podejście do pracy socjalnej z rodziną [A new approach to social work with the Family]. In: E. Kantowicz (Ed.) Koncepcja i praktyka działania społecznego w pracy socjalnej [The concept and practice of social action in social work] (pp. 13-24). Olsztyn: Wydawnictwo UWM.

[3] Ciczkowska-Giedzun, M. (2011b). Praca socjalna oparta na zasobach [Social work based on resources]. Rocznik Socjologii Rodziny [Sociology Of The Family Yearbook], vol. XXI, 213-228.

[4] Cowger, C. D. (1994). Assessing client strengths: clinical assessment for client empowerment. Social Work, 39/3, 262-268. 
[5] DuBois, B. L., \& Miley, K. K. (2005). Social Work: An Empowering Profession. Boston: Ablongman Pearson.

[6] Duranowski, W. (2013). Podejście oparte na empowermencie w pracy socjalnej [Empowerment based approach in social work]. Empowerment. O polityce aktywnej integracji [Empowerment - Active integration policy], 1, 29-38.

[7] Gkorezis, P., Hatzithomas, L., \& Petridou, E. (2011). Impact of Leader's Humor on Employees' Psychological Empowerment: the Moderating Role of Tenure. Journal of Managerial Issues, vol. XXIII, 83-95.

[8] Global Definition of Social Work. (2014). Retrieved from www.ifsw.org/policies/ definition-of-social-work/.

[9] Grewiński, M., \& Krzyszkowski, J. (2012). Wybrane aspekty międzynarodowej polityki społecznej - pomoc społeczna i aktywna integracja [Selected aspects of international social policy-social assistance and active integration]. Warszawa: MCPS.

[10] Gulczyńska, A., \& Granosik, M. (Eds.). (2014). Empowerment w pracy socjalnej: praktyka $\mathrm{i}$ badania partycypacyjne [Empowerment in social work: practice and participatory research]. Warszawa: CRZL.

[11] Hardina, D. (2005). Ten characteristics of empowerment-oriented social service organizations. Administration in Social Work, 29/3, 23-42.

[12] Hardina, D., Middleton, J., Montana, S., \& Simpson, R.S. (2007). An Empowering Approach to Managing Social Service Organizations. New York: Springer.

[13] Kanafa-Chmielewska, D. (2012). Umacnianie (Empowerment) - pojęcie i istota [Strengthening (Empowerment) - a concept and essence. Współczesne Zarządzanie [Modern Management], 1, 130-140.

[14] Krasiejko, I. (2010). Metodyka działania asystenta rodziny. Podejście Skoncentrowane na Rozwiązaniach [The methodology of family Assistant action. Approach Focused on Solutions]. Katowice: „Śląsk”.

[15] Krawczyk-Bryłka, B. (2012). Empowerment - strategia zarządzania oparta na zaufaniu [Empowerment - A management strategy based on trust]. The Central European Journal of Social Sciencies and Humanities, 4/1, 313-330.

[16] Krzyszkowski, J. (2011). Analiza doświadczeń w obszarze pracy socjalnej i polityki społecznej [Analysis of experiences of social work and social policy area]. In: B. Skrzypczak (Ed.) Organizowanie społeczności lokalnej. Analizy. Konteksty. Uwarunkowania [Organisation of the local community. Analysis. Contexts. Conditioning] (pp. 17-35). Warszawa: ISP, CAL.

[17] Lee, J .A. B. (2001). The Empowerment Approach to Social Work Practice. Building the Beloved Community. New York: Columbia University Press.

[18] Manifest Forum Współpracy Empowerment. O urzeczywistnienie zasady Empowerment w polityce aktywnej integracji [Manifesto of Empowerment Cooperation Forum. About realization Empowerment on the active inclusion policy]. (2014). Retrieved from http://ops.pl/ wp-content/uploads/2014/09/Manifest-empowerment-projekt.pdf, 1-6.

[19] Moczydłowska, J. (2013). Empowerment - upodmiotowienie we wspólnocie [Empowerment in the community]. Ekonomika i Organizacja Przedsiębiorstwa [Economics and Organization of the Enterprise], 11, 15-23.

[20] Moczydłowska, J. (2014). Empowerment - nowe spojrzenie na aktywowanie potencjału ludzkiego organizacji [Empowerment - a new look on activating the human potential of the organization]. Zeszyty Naukowe Wyższej Szkoły HUMANITAS. Zarządzanie [Scientific Notebooks HUMANITAS. Management], 1, 71-78.

[21] Mussato C., Senior B. \&, Pollefait R. (2015). Dziennik badawczy zespołu naukowo-badawczego (actionresearchgroup): Rozwój upodmiotowienia wychowawców i beneficjentów w pracy z osobami dorosłymi wykluczonymi społecznie. Część druga (19-22 maja 2015) [Research journal team science and research (actionresearchgroup): the development of empowerment of educators and beneficiaries in working with socially excluded adults. Part 2, 19-22 may 2015].

[22] Mussato, C. \&, Pollefait R. (2014). Dziennik badawczy zespołu naukowo-badawczego (action research group): Rozwój upodmiotowienia wychowawców i beneficjentów w pracy z osobami dorosłymi wykluczonymi społecznie. Część pierwsza (12-28 maja 2014) [Research journal team science and research (actionresearchgroup): the development of empowerment of 
educators and beneficiaries in working with socially excluded adults. Part 1, 12-28 may 2014].

[23] Olejniczak, K. (2013). Doświadczenia administracji w Stanach Zjednoczonych [Experiences of administration in the United States]. In: S. Mazur, \& A. Płoszaj (Eds.) Zarządzanie wiedzą w organizacjach publicznych. Doświadczenia międzynarodowe [Knowledge management in public organizations. International experience] (pp. 188-215). Warszawa: Scholar.

[24] Ornacka, K. (2013). Od socjologii do pracy socjalnej: społeczny fenomen dzieciństw [From sociology to social work: social phenomenon of childhood]. Kraków: Wydawnictwo Uniwersytetu Jagiellońskiego.

[25] Osborne, D., \& Gaebler, T. (2005). Rządzić inaczej [Reinventing Government]. Poznań: Media Rodzina.

[26] Radlińska, H. (1961). Pedagogika społeczna [Social pedagogy]. Wrocław: Zakład Narodowy im. Ossolińskich.

[27] Słowniczek OSL [Glossary OSL]. (2016). Retrieved from http://www.osl.org.pl/ slowniczek-osl/.

[28] Słownik równość.info [Dictionary equality.info]. (2016). Retrieved from http://rownosc. info/dictionary/empowerment/.

[29] Strona internetowa Katedry Pedagogiki Opiekuńczej i Profilaktyki Społecznej. Uniwersytet Kazimierza Wielkiego. Bydgoszczy. Erasmus + [Website Pedagogy of Care and Social Prevention Department. Kazimierz Wielki University. Bydgoszcz. Erasmus +]. (2016). Retrieved from http://www.pedagogikaopiekuncza.ukw.edu.pl/jednostka/katedra_pedagogika_ opiekuncza/projekt_erasmus.

[30] Szarfenberg, R. (2007). Definicje, zakres i konteksty polityki społecznej [Definitions, scope and social contexts]. In: G. Firlit-Fesnak, M. Szylko-Skoczny (Eds.). Polityka społeczna [Social Policy]. Warszawa: Wydawnictwo Naukowe PWN.

[31] Szarfenberg, R. (2008). Krytyka i afirmacja polityki społecznej [Criticism and affirmation of social policy]. Warszawa: IFiS PAN.

[32] Szarfenberg, R. (2015). Empowerment - krótkie wprowadzenie (wersja 2.0, 07.08.2015) [Empowerment - a short introduction (version 2.0, 07.08.2015)]. Warszawa: Instytut Polityki Społecznej Uniwersytet Warszawski.

[33] Szmagalski, J. (1994a). O „budzeniu sił ludzkich” nie po polsku: koncepcje empowerment w anglojęzycznej literaturze z zakresu edukacji i pracy socjalnej ["Raising human force" not in Polish: concepts of empowerment in English-language literature, education, and social work]. Kwartalnik Pedagogiczny [Pedagogical Quarterly], 3, 131-152.

[34] Szmagalski, J. (1994b). Teoria pracy socjalnej a ideologia i polityka społeczna. Przykład amerykański [Theory of social work and ideology and social policy. An example of an American]. Warszawa: UW.

[35] The pictures taken in Valencia. (2016). Retrieved from https://www.flickr.com/photos/ 133203254@N03/sets/72157668821147015/;

[36] The seminar, Spanish version on Youtube. (2016). Retrieved from https://www. youtube.-com/watch?v=jVi_IP24iqQ.

[37] Trawkowska, D. (2013). Empowerment - idea, koncepcje i praktyka w pracy socjalnej [Empowerment - the idea, concepts, and practice in social work]. Empowerment - o polityce aktywnej integracji [Empowerment - the active policy of integration], 2, s. 38 - 43.

[38] Trawkowska, D. (2014). Czym są dobre praktyki w pomocy społecznej [What are good practices in social assistance]. Empowerment - o polityce aktywnej integracji [Empowerment - the active policy of integration], 1 (4), s. 10-16.

[39] Wolfensberger, W. (2011). Social Role Valorization and, or Versus. "Empowerment". Intellectual and Developmental Disabilities, 49/6, 468-476. 